\section{NEUROAKSIJALNA ANESTEZIJA U PRISUSTVU TETOVAŽE NA LEĐIMA (Neuroaksijalna anestezija)}

\author{
Dragana Unić-Stojanović
}

${ }^{1}$ Institut za kardiovaskularne bolesti „Dedinje”

${ }^{2}$ Medicinski fakultet Univerziteta u Beogradu

\title{
NEUROAXIAL ANAESTHESIA IN THE PRESENCE OF BACK TATTOOS (Neuroaxial anaesthesia)
}

\author{
Dragana Unić-Stojanović
}

${ }^{1}$ Department of anesthesiology, Cardiovascular Institute Dedinje, Belgrade

${ }^{2}$ Medical school University of Belgrade

\section{Apstrakt:}

Uvod: Neuroaksijalna anestezija se koristi za obezbeđenje analgezije tokom i posle operacije, za lečenje hroničnih bolnih stanja ili za postizanje analgezije tokom porođaja. Međutim, poslednjih godina, tetovaže na neuobičajenim mestima, kao što je lumbalni deo leđa, postaju sve modernije i zastupljenije, što može da predstavlja problem za izvođenje tehnika neuroaksijalne anestezije. Do danas nema sistematičnog revijalnog prikaza ni randomizovane kontrolisane studije u kojima je predmet istraživanja izvođenje neuroaksijalne anestezije u prisustvu tetovaže na mestu izvođenja. Prikaz slučaja: Predstavićemo slučaj pacijentkinje stare 35 godina, koja je primljena u naš Institut radi elektivne operacije varikozno izmenjenih vena donjih ekstremiteta. Tokom preoperativne pripreme, utvrđeno je prisustvo velike tetovaže preko celog lumbalnog regiona, uz nemogućnost da se izvede neuroaksijalna anestezija bez istovremene punkcije pigmentovanog dela kože. Odlučeno je da se operacija uradi u opštoj anesteziji. Diskusija i zaključak: Osnovni rizik izvođenja neuroaksijalne anestezije u regionu tetovaže je mogućnost uvođenja pigmenta tetovaže u subarahnoidalni ili epiduralni prostor. Iako do danas nema publikovanih kliničkih komplikacija koje su direktno povezane sa plasiranjem epiduralne ili spinalne igle na mestu tetovaže, smatra se da je to zbog činjenice da je u prošlosti manji broj pacijenata imao tetovažu u regionu donjeg dela leđa. Takođe, komplikacije ne moraju odmah da se uoče, jer je potrebno vreme da nastanu. Zbog rizika uvođenja pigmenta u intratekalni ili epiduralni prostor epiduralnom iglom koja prolazi kroz kožu na kojoj je tetovaža, u odsustvu jasnih stavova i preporuka, savetuje se individualan pristup baziran na proceni rizika $i$ koristi takve vrste anestezije za pacijenta, želji pacijenta i iskustvu anesteziologa.

Autor za korespondenciju: Dragana Unić-Stojanović, Institut za kardiovaskularne bolesti „Dedinje”, Beograd, Milana Tepića 1, Telefon: +381 64 8431103, E-mail: dragana.unic@gmail.com

\section{Sumarry}

Introduction: Neuroaxial anaesthesia is used for pain control during or after surgery, to treat chronic pain states or to decrease labor and delivery pain in the parturient population. In recent years body tattooing on unusual sites such as the lumbar area have increased in popularity, and may be associated with problems during performing neuroaxial anaesthesia technique. Until now, there were no systematic reviews nor randomized control studies that investigated, primarly, the performance of neuroaxial anaesthesia through a tattoo. Case report: We report a case of a 35-year-old lady who was admitted to our hospital for veins surgery. Preanaesthetic back examination revealed an extensive tattoo covering the entire of her lumbar region with no possibility of performing neuroaxial anaesthesia without penetrating pigment containing skin. It was decided to perform surgery under general anaesthesia. Discussion and conclusions: The main safety concern in performing neuraxial anaesthesia through a tattoo is in the presence of the pigment of the tattoo in the intrathecal or the epidural spaces. Although to date, there are no reported complications from inserting an epidural or spinal needle through the tattoo, this could be because in the past, fewer patients had tattoos involving the midline of the lower back. Also, complications may take time to develop and it may be too early to see these complications which may occur later in time. Therefore, because of safety concerns of introducing pigment into the intrathecal or epidural spaces with the use of hollow needles through tattoos during neuraxial anaesthesia, and no specific guidelines to follow, a safe individual approach should be attempted based on risk/benefit assesment for patient and experience of the anaesthesiologist.

Corresponding author: Dragana Unić-Stojanović, Cardiovascular Institute Dedinje, Heroja Milana Tepića 1 street, 11000 Belgrade, Serbia, Telephone: +381 64 8431103, E-mail: dragana.unic@gmail. com 
Ključne reči: neuroaksijalna anestezija; epiduralna; tetovaže na leđima; rizik

\section{Uvod}

$\mathrm{N}_{\mathrm{b}}^{\mathrm{e}}$ euroaksijalna anestezija se koristi za obezbeđenje analgezije tokom i posle operacije, za lečenje hroničnih bolnih stanja, kao i za postizanje analgezije tokom porođaja. Kliničke studije su pokazale da primena regionalne anestezije ima povoljne efekte i smanjuje učestalost srčanih i respiratornih komplikacija. ${ }^{1}$ Postoperativna kontrola bola epiduralnom analgezijom se u mnogim studijama pokazala kao bolja od drugih tipova analgezije. Bolja kontrola bola dovodi do manje neželjenih efekata u postoperativnom periodu (hipertenzija, tahikardija, povećani katabolizam, poremećaj imunog odgovora, poremećaj hemostaze) ${ }^{1}$.

Međutim, tetovaže na telu, prisutne još pre nove ere, postaju sve popularnije. Prema istraživanju sprovedenom u Americi, 2004. godine, oko 36\% stanovnika mlađih od 40 godina ima bar jednu tetovažu. ${ }^{2}$ Poslednjih godina, tetovaže na neuobičajenim mestima postaju sve modernije i zastupljenije i kod žena se sve češće sreću u središnjem delu lumbalnog regiona leđa. ${ }^{3}$ Međutim, do danas nema sistematičnog revijalnog prikaza ni randomizovane kontrolisane studije u kojima je predmet istraživanja izvođenje neuroaksijalne anestezije u prisustvu tetovaže na mestu izvođenja. Cilj ovog rada je da se prikažu opšti principi i stavovi u pogledu davanja anestezije u prisustvu tetovaže na mestu planiranog izvođenja neuroaksijalne anestezije.

\section{Prikaz slučaja}

Predstavićemo slučaj pacijentkinje stare 35 godina, koja je u dobrom opštem stanju (ASA FS skor 1 - Skor fizičkog statusa Američkog društva Anesteziologa) primljena u Institut za kardiovaskularne bolesti „Dedinje” radi elektivne operacije varikozno izmenjenih vena donjih ekstremiteta. Planirano je da se navedena operacija izvede u epiduralnoj anesteziji, koja je uobičajena anesteziološka tehnika u našem Institutu za navedenu proceduru. Tokom preoperativne pripreme, utvrđeno je prisustvo velike tetovaže preko celog lumbalnog regiona
Key wards: neuroaxial anaesthesia; epidural; tattoos; back risk

leđa, uz nemogućnost da se izvede neuroaksijalna anestezija bez istovremene punkcije pigmentovanog dela kože. Anesteziolog je predočio pacijentkinji prednosti i nedostatake izvođenja procedure u opštoj ili epiduralnoj anesteziji. Kada je u pitanju epiduralna anestezija, navedeno je da nema publikovanih komplikacija direktno povezanih sa primenom ove vrste anestezije u prisustvu tetovaže na mestu punkcije. Međutim, ne može se sa sigurnošću tvrditi da postoji odsustvo bilo kakvih posledica, s obzirom na to da je potrebno vreme da se razviju komplikacije i da se posle dugog perioda vremena nastanak komplikacija i ne mora dovesti u direktnu vezu sa punkcijom na mestu tetovaže. Nakon razgovora, pacijentkinja i anesteziolog su doneli odluku da se navedena operacija uradi u opštoj anesteziji.

\section{Diskusija}

Susrevši se sa slučajem naše pacijentkinje, postavili smo pitanja: da li ubod epiduralnom iglom kroz pigmentovanu tetovažu može uzrokovati komplikacije i da li se neuroaksijalna anestezija može bezbedno izvesti?

Mastilo za tetoviranje sadrži različita organska i neorganska jedinjenja, mešavine soli metala i rastvarače. Sastav boja bi, po pravilu, trebalo da bude kontrolisan i odobren pre pojave na tržištu. Pokazano je da soli metala mogu da budu uzrok kožnih alergijskih reakcija, hroničnih i sistemskih bolesti ${ }^{4}$. Tattoo umetnici kombinuju te mešavine mastila sa drugim supstancama kao što su etanol, izopropil-alkohol ili glicerin, na osnovu njihovog ličnog iskustva i u cilju dobijanja različitih nijansi boja. Vrlo često ni tattoo majstori ni korisnici ne znaju sastav mastila korišćenog za tetoviranje $e^{4}$.

Teoretski, prilikom plasiranja kroz tkivo, bilo epiduralne ili spinalne igle, postoji rizik da se otkine tkivni fragment. To prevashodno može nastati kada se koriste velike igle bez stileta, mada je opisano i posle upotrebe Quincke-ove spinalne igle dijametra 25-gauge5. Injekcija kroz iglu u čijem lumenu je otkinuto tkivo dovodi do deponovanja 
otkinutog tkiva u dubljim strukturama ${ }^{6,7}$. Tokom procesa tetoviranja, igle penetriraju epidermis do dermisa i pigment se deponuje duž celog puta igle. Samo pigment $\mathrm{u}$ dermisu permanentno ostaje. Pošto tetovaža zaraste, pigment biva preuzet od strane makrofaga i dospeva u limfni sistem ${ }^{8}$. Pigment u vezivnom tkivu dermisa daje boju tetovaži. Koje su moguće implikacije na anesteziologa? Upravo mogućnost da se tkivo koje sadrži pigment (različite kancerogene i citotoksične boje) može uneti u epiduralni ili subarahnoidalni prostor je najčešći razlog zašto se anesteziolozi u praksi uzdržavaju od plasiranja epiduralnog katetera kod bolesnika koji u regionu kičmenog stuba imaju tetovaže. Uneti pigment može biti uzrok hemijskog arahnoiditisa ili razvoja epidermoidnog tumora ${ }^{8}$. Pri tome, komplikacije ne moraju odmah da budu uočljive jer mogu da budu potrebne i godine da se razviju i jasno ispolje.

Do danas nema publikovanih jasnih komplikacija direktno povezanih sa insercijom epiduralne igle kroz tetovažu. Publikovan je samo jedan slučaj pacijentkinje koja je imala obojenu tetovažu preko celih leđa i kod koje je za porođaj korišćena epiduralna analgezija (nivo L2-L3 intervertebralni prostor) ${ }^{6}$. Kliničke manifestacije su obuhvatile bolnu osetljivost, spontano i na dodir, i osećaj pečenja na mestu plasiranog epiduralnog katetera, nekoliko sati posle izvedenog epiduralnog bloka. Neurološki nalaz je bio uredan i simptomi su se spontano povukli posle $24 \mathrm{~h}$. Mada definitivan uzrok za nastanak te lumbalne iritacije nije poznat, taj slučaj je podstakao na razmišljanje da je otkinut deo tetoviranog tkiva (tissue coring) precipitirajući faktor. Drugi prikazi serija i pojedinačnih slučajeva nisu pokazali jasne dokaze za prisustvo negativnih posledica udruženih sa insercijom epiduralne igle kroz tetoviranu kožu ${ }^{8-10}$. Dodatno, navedeni simptomi mogu biti uzrokovani traumom tkiva koja je nastala ubodom epiduralne igle i koja se susreće i kod bolesnika bez tetovaže ${ }^{5}$. Istraživanje u Engleskoj je pokazalo da $65 \%$ anesteziologa za bezbolni porođaj koristi spinalnu ili epiduralnu anesteziju i u prisustvu tetovaže na mestu uboda ${ }^{7}$. Prema mom saznanju, nema publikovanih podataka o izvođenju neuroaksijalne anestezije $u$ prisustvu tetovaže u našoj zemlji.

Činjenica da ne postoje publikovane komplikacije posle epiduralne anestezije na mestu tetovaže treba oprezno da se prihvati i tumači, jer bi mogla da ukazuje na to da se zaista nisu ni desile i da se neuroaksijalna anestezija kod tih pacijenta može bezbedno izvoditi, ali i da je u prošlosti mali broj pacijenata (porodilje i drugi) imao tetovažu u središnjem donjem delu leđa, tako da kod njih nije ni izvođena ta vrsta anestezije ${ }^{7}$. Dodatno, epidermoidni tumori i arahnoiditis ${ }^{11}$ ne nastaju odmah posle dejstva uzročnog faktora već tokom vremena. Moguće je da je još uvek suviše rano da se vide dugoročne komplikacije $\mathrm{e}^{7}$.

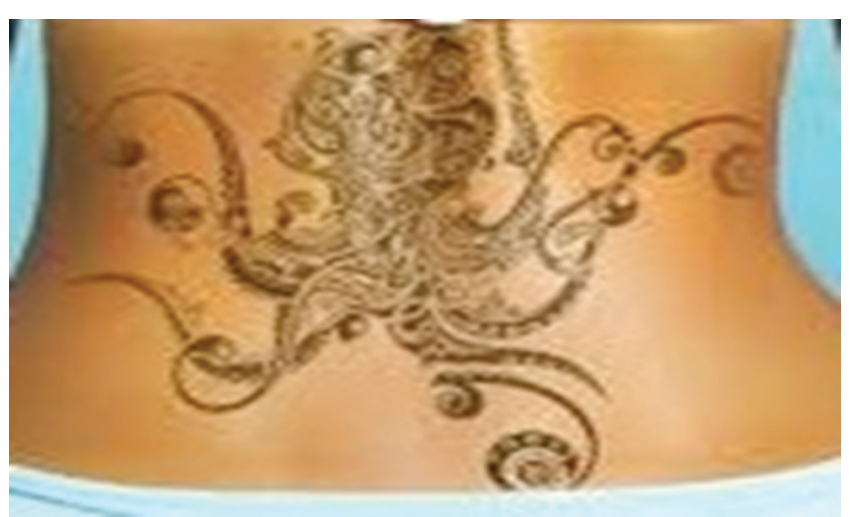

Slika 1: Tetovaža u lumbalnom delu leđa

Preporučuje se da se pre primene epiduralne anestezije koža bolesnika detaljno pregleda, što smo mi i uradili kod naše pacijentkinje. Nakon utvrđivanja prisustva tetovaže na mestu na kome se planira plasiranje epiduralnog katetera, u odsustvu jasnih preporuka i vodiča, preporučuje se individualni pristup bolesniku. Plan anestezije bi trebalo da se napravi posle razgovora sa bolesnikom, pošto mu se prethodno daju najvažnije informacije vezane za neuroaksijalnu anesteziju i prisustvo tetovaže na mestu uboda. Bolesnik bi trebalo da se obavesti da nema do sada poznatih ozbiljnih komplikacija vezanih za primenu neuroaksijalne anestezije na mestu tetovaže, čak i kada se izvede direktno kroz mesto tetovaže, kao i da se sumnja u postojanje teoretskog rizika od komplikacija ${ }^{5}$. S obzirom na to da je još uvek rano da se odbaci mogućnost dugoročnih posledica, preporučuje se: izbegavanje direktne punkcije tetovirane kože iglom, bilo izborom drugog (čistog) intervertebralnog prostora, primenom paramedijalnog pristupa ili pronalaženjem delića kože bez pigmenta unutar tetovaže; kao i pravilno postavljanje unutrašnjeg stileta celom dužinom u Touhy iglu pre početka punkcije, kako bi se smanjio rizik otkidanja i unošenja tkiva ${ }^{5,12}$. Mi smo kod naše pacijentkinje ana- 
lizirali kožu od L1-L2 do L4-L5 međupršljenskog prostora u cilju pronalaženja malog čistog dela na kome bismo izveli punkciju. Međutim, u tom regionu koža je bila potpuno prekrivena tetovažom. Kada se preporučene opcije ne mogu implementirati, sugeriše se incizija kože kroz epidermis, nekoliko milimetara u dermis, pre insercije igle, kako bi se sprečio bilo koji rizik od unošenja pigmenta ${ }^{5}$.

\section{Zaključak}

Do danas ne postoje podaci o teškim komplikacijama posle primene spinalne ili epiduralne anestezije ubodom na mestu tetovaže. Preporučuje se da se izbegne direktna punkcija tetovaže ili kada se ne može, izbeći da se koža zareže pre insercije igle kroz tetovažu.

\section{Literatura}

1. Unic-Stojanovic D, Babic S, Jovic M. Benefits, risks and complications of perioperative use of epidural anesthesia. Med Arh 2012; 66(5):340-343.

2. Laux P, Tralau T, Tentscher t J, Blume A, Dahouk SA, Baumler W, et al. A medical-toxicological view of tattooing. Lancet 2016; 387(10016):395-402.
3. Jericho BG. Neuraxial anesthesia through tattoos: is it safe puncturing the dragon? Internet J Anesth 2009; 20(1):11.

4. Houhoulis K, Lewis K, Fasone R, Brian E. Benham BE. Tattoos and administration of regional anesthesia: a comprehensive systematic review protocol. JBI Database System Rev Implement Rep 2016;14(10):48-63.

5. Mercier F, Bonnet MP. Tattooing and various piercing: anaesthetic considerations. Curr Opin Anaesthesiol 2009; 22:436-441.

6. Kuczkowski KM. Labour analgesia in a parturient with lumbar tattoo: a routine management? or not? Can J Anaesth 2004; 51:93.

7. Shanbhag S, Chilvers R. Tattoo and regional anaesthesia. Internet J Anesthesiol 2008; 18(2).

8. Douglas MJ, Swenerton JE. Epidural anesthesia in three parturients with lumbar tattoos: a review of possible implications. Can J Anesth 2002; 49:1057-60.

9. Kuczkowski KM, Hope RD. (New) Images in obstetric anesthesia: lumbar tattoos. Ann Fr Anesth Reanim 2006; 25(1):74-78.

10. Coimbra P, Peixoto J, Barros N, Fernandes C, Matias C, Marques A. Epidural analgesia in parturient with lumbar tattoo. Reg Anesth Pain Manage 2007; 32 (5 suppl 1):77.

11. Ferraz IL, Barros GA; Ferreira Neto PG, et al. Does spinal block through tattooed skin cause histological changes in nervous tissue and meninges?: an experimental model in rabbits. Reg Anesth Pain Med 2015; 40(5):533-538.

12. Welliver D, Welliver M, Carroll T, James P. Lumbar epidural catheter placement in the presence of low back tattoos: a review of the safety concerns. AANA 2010; 78(3): 197-201. 